\title{
STRATEGI PEMERINTAH DAERAH DALAM PENGEMBANGAN PELAYANAN BERBASIS E- GOVERNMENT DI KABUPATEN MUNA
}

\author{
Hamrun $^{1}$, Ahmad Harakan ${ }^{2}$, Andi Luhur Prianto ${ }^{3}$, Nur Khaerah ${ }^{4}$ \\ ${ }^{1,2,3,4}$ Program Studi Ilmu Pemerintahan, Fakultas Ilmu Sosial dan Ilmu Politik, Universitas Muhammadiyah \\ Makassar, Indonesia.
}

Email:Hamrun@unismuh.ac.id, ahmad.harakan@unismuh.ac.id,luhur@unismuh.ac.id, nurkhaerah@unismuh.ac.id

\begin{abstract}
ABSTRAK
Di era Revolusi Industri 4.0 kinerja pemerintahan dalam mewujudkan pelayanan publik yang berkualitas meskipun berada pada pulau yang jauh dari ibukota negara menjadi tantangan bagi stakeholder pemerintahan. Hal ini terjadi dikarenakan pemerataan pembangunan dan kesuksesan pelayanan publik maka pemerintah perlu melakukan bebagai upaya penyediaan fasilitas pelayanan publik yang efektik dan efisien, termasuk memberikan pelayanan berbasis e-government. Artikel ini akan menganalisa dan mengulas dari aspek strategi pengembangan program yang melibatkan sumber daya manusia dan teknologi informasi dengan output pelayanan prima. Meski Realisasi pengembangan pelayanan berbasis e-government di Kabupaten Muna menghadapi banyak tantangan baik dalam hal geografis, ekonomi, teknologi, politik, maupun budaya, namun pelaksanaannya sangat ditunggu oleh masyarakat setempat. Selain itu pelayanan berbasis e-government merupakan tuntutan di era revolusi industri 4.0 saat ini.
\end{abstract}

Kata Kunci: E-Government, Pelayanan Publik, Teknologi Informasi

\section{PENDAHULUAN}

Perkembangan sistem teknologi informasi yang ada di tanah air tidak dapat dilepaskan dari system global. Seakan Indonesia saat ini merupakan bagian dari apa yang oleh Mc Luhan (Ien Ang,1994) [1]disebut sebagai "desa global". Tidak ada lagi tempat di tanah air terisolasi Karena semuanya telah dihubungkan dengan jaringan komunikasi global, dimana komunikasi itu tidak saja menembus batas-batas wilayah tetapi juga budaya bahkan menipiskan batas personal. Indonsia saaat ini didibukkan dengan tidak saja perkembangan media cetak (surat kabar, majalah, tabloid, dll), media elektronik (radio, radio satelit,/world Space, Televisi, Televisi Satelit, dll), tetapi juga perkembangan komunikasi multi mdia,(jaringan, telepon seliler, internet, email, dll).dengan demikian ruang public nbagi warga Negara menjadi semakin meluas. Proses-proses politik tidak saja terjadi dalam media cetak dan media elektronik tetapi harus diakui secara lambat tetapi pasti juga berlangsung melalui internet. Atau diruang Cyber.bahkan melalui internet warga Negara bisa melakukan konfrensi jarak jauh untuk mendiskusikan sesuatu hal yang berkaitan dengan perumusan kebijakan publik.

Perkembangan teknologi yang dibarengi dengan inovasi pelayanan publik di ranah pemerintahan tentunya menuntut setiap instansi untuk mengikuti arus tersebut. Pemanfaatan Teknologi Informasi dan Komunikasi (TIK) telah memasuki 
berbagai segi kehidupan baik individu, keluarga, organisasi maupun masyarakat, serta mengalami perkembanagan yang sangat cepat dan masif.Perkembangan TIK yang sedemikian cepatnya telah membawa dunia memasuki era baru yang lebih cepat dari yang pernah dibayangkan sebelumnya (Indrajit, 2006,)[2]. Era baru inilah yang sekarang disebut sebagai era informasi, yang didukung satu kekuatan TIK yang dikenal dengan ICT (information communication and technology) dimana mempunyai pengaruh besar dalam kehidupan manusia sehari-hari, seperti cara kerja dan mengelola organisasi (Slamet, dkk., 2008)[3]

Di Indonesia, inovasi e-government sudah diinisiasi sejak beberapa tahun belakangan ini. Selain adanya kebutuhan, baik pemerintah pusat maupun pemerintah daerah akan sebuah sistem yang terintegrasi, pengembangan e-government di Indonesia didukung oleh Instruksi Presiden Republik Indonesia Nomor 3 Tahun 2003 tentang Kebijakan dan Strategi Nasional Pengembangan egovernment dan didukung pula oleh regulasi yang terkait seperti UndangUndang No. 14 tahun 2008 tentang Keterbukaan Informasi Publik, serta Peraturan Pemerintah No. 61 tahun 2010 tentang Implementasi Undang-Undang Keterbukaan Informasi Publik. Menyikapi perkembangan dunia saat ini hampir semua aspek kegiatan selalu berhubungan dengan informasi. Pada tahun 2015, sebesar 50\% dari penduduk Indonesia sudah masuk ke masyarakat informasi global (global information society). Sejalan dengan semangat reformasi birokrasi di Indonesia, e-government semakin berperan dalam meningkatkan kualitas pelayanan publik serta membantu proses penyampaian informasi secara lebih efektif kepada masyarakat. Perlu disadari dan dipahami bahwa sesuai amanat UUD 1945 Pasal 18 Ayat (2) dan Pasal 34 ayat (3), maka peningkatan pelayanan publik (public service) harus mendapatkan perhatian utama dari pemerintah, karena pelayanan publik merupakan hak-hak sosial dasar dari masyarakat (social rights) ataupun hak yang mendasar (fundamental rights).

Pelayanan umum yang bersifat mengatur dan penyediaan kebutuhan umum, disertai bentuk-bentuk pelayanannya. Struktur penyelenggara layanan dan kesiapan institusinya serta tuntutan zaman terhadap pelayanan umum masa depan yang berbentuk e-government. Pemanfaatan e-government adalah untuk meningkatkan efisiensi dan efektivitas instansi pemerintahan memberikan informasi dan pelayanan, hal ini berarti mempercepat proses dan menghemat biaya E-Government merupakan penggunaan teknologi informasi oleh pemerintah untuk memberikan informasi dan pelayanan bagi warganya. E-Government adalah proses pemanfaatan teknologi informasi adalah untuk membantu menjalankan sistem pemerintahan secara lebih efisien.

Dalam hal program pembangunan e-government, Pemerintah Kabupaten Muna melalui Dinas Komunikasi Informatika, memiliki peran untuk mengelola penyelenggaraan data elektronik atau e-government. Pemerintah Kabupaten Muna melalui Dinas kominfo sangat berkewajiban untuk melakukan penyiapan, perumusan, dan pelaksanaan kegiatan di bidang infrastruktur teknologi, pengembangan pengelolaan aplikasi serta keamanan informasi dan komunikasi. Program pemerintah kabupaten Muna 
untuk mengembangkan pelayanan berbasis e-government sangat dituntut untuk mempermudah masyarakat dalam menerima layanan dari pemerintah kabupaten Muna.

Realisasi pengembangan egovernment Di Kabupaten Muna menghadapi banyak tantangan baik dalam hal geografi, ekonomi, teknologi, politik, maupun budaya. Dalam proses implementasi, ditemukan beberapa fenomena yang menunjukkan implementasi e-government masih berjalan lambat. Jika mengacu pada seluruh daerahdaerah maju sebagian di Indonesia sangaat di dukung oleh kemajuan melayani masyarakat dengan mengacu pada pelayanan berbasis e-government. Agar setara dengan daerah- daerah lain yang di Indonesia, pemerintah Kabupaten Muna harus punya perencaaan yang baik. Saat ini jaringan komunikasi antar daerah yang ada di wilayah kabupaten Muna tidak merata. Masih banyak wilayah-wilayah yang ada di dikabupaten muna seperti batukara dan pasikolaga belum terjangkau oleh jaringanjaringan telekomunikasi maupun internet.

\section{KERANGKA TEORI Konsep Strategi}

Strategi memiliki banyak sekali definisi dalam perkembangannya sebagai sebuah konsep. Strategi sendiri berasal dari bahasa Yunani yakni strategeia,yang memiliki arti kepemimpinan dalam ketentaraan. Dalam perkembangannya, definisi konsep strategi semakin banyak dan selalu berkembang dari tahun ke tahun. Hal tersebut dapat diperhatikan dari beberapa konsep berbeda mengenai strategi berikut ini :

Rivai dan Darsono (2015)[4]:

Strategi ialah cara dan alat yang digunakan untuk mencapai tujuan akhir (sasaran atau objektif). Strategi harus mampu membuat semua bagian dari suatu organisasi yang luas menjadi satu, terpadu untuk mencapai tujuan akhir (sasaran/objektif); ini adalah masalah kegiatan operasi organisasi. Thompson dan Strickland (2001) Strategi terdiri ats kombinasi dari pergerakan kompetitif dan pendekatan bisnis yang digunakan manajer untuk memuaskan pelanggan, berhasil dalam bersaing, dan mencapai tujuan-tujuan organisasi. Gamble, Thompson, dan Peteraf (2013) Strategi adalah serangkaian pergerakan kompetitif dan pendekatan bisnis untuk menggerakkan perusahaan pada arah yang dikehendaki, memancangkan posisi pada pasar, memikat konsumen, dan mencapai target finansial serta kinerja pasar.

Mulyadi (2014) Strategi adalah pola tindakan utama yang dipilih untuk mewujudkan visi perusahaan, melalui misi. Henderson (1989) Strategi adalah pencarian yang dilakukan secara hati-hati untuk perencanaan aksi yang akan mengembangkan keunggulan bersaing perusahaan dan juga menyatukannya. Bagi setiap perusahaan, pencarian tersebut adalah suatu proses berulang yang dimulai dengan pengakuan terkait dimana anda sekarang, dan apa yang anda punya sekarang.

Instruksi Presiden No. 3 tahun 2003[5] mengenai kebijakan dan strategi nasional pengembangan E-government menjadikan e-government sangat layak untuk diterapkan sebagai bentuk dukungan dari pengembangan pelayanan kepada masyarakat. Berikut 6 strategi pemerintah dalam penyusunan e-government:

1. Mengembangkan sistem pelayanan yang andal, terpercaya, serta terjangkau masyarakat luas. Hal tersebut salah 
satunya dicapai dengan pemerataan jaringan komunikasi baik wilayah maupun kualitasnya serta pembentukan portal informasi pemerintahan.

2. Menata sistem dan proses kerja pemerintah dan pemerintah otonom secara holistik. Maksudnya adalah persiapan SDM dalam pemerintahan agar beradaptasi dengan sistem yang sudah memanfaatkan teknologi informasi dan komunikasi.

3. Memanfaatkan teknologi informasi dan komunikasi secara optimal. Selain daripada penyajian informasi yang lengkap, keamanan transaksi layanan public juga menjadi hal utama dalam pemanfaatan teknologi informasi dan komunikasi.

4. Meningkatkan peran serta dunia usaha dan mengembangkan industri telekomunikasi dan teknologi informasi. Peran dunia usaha cenderung kepada partisipasi dalam pemanfaatan e-government sehingga pelayanan public tidak sepenuhnya dilayani pemerintah.

5. Mengembangkan kapasitas sumber daya manusiabaik pada pemerintah maupun pemerintah daerah otonom disertai dengan peningkatan e-literacy masyarakat.

6. Melaksanakan pengembangan secara sistematik melalui tahapan yang realistic dan terukur yaitu melalui tahapan persiapan, pematangan, pemantapan, dan pemanfaatan.

\section{E-Government}

Menurut Indrajit Loc.cit. (2002)[2] E-government merupakan suatu mekanisme interaksi baru antara pemerintah dengan masyarakat dan kalangan lain yang berkepentingan, dengan melibatkan penggunaan teknologi informasi (terutamainternet) dengan tujuan memperbaiki mutu (kualitas) pelayanan. E-Government adalah penyelenggaraan kepemerintahan berbasiskan elektronik untuk

meningkatkan kualitas layanan publik secara efisien, efektif dan interaktif. Dimana pada intinya E-Government adalah penggunaan teknologi informasi yang dapat meningkatkan hubungan antara pemerintah dan pihak-pihak lain (penduduk, pengusaha, maupun instansi lain). E-Government sering digambarkan atau dideskripsikan secara cukup beragam oleh masing-masing individu atau komunitas. Hal ini disebabkan karena berbagai hal:

a. Walaupun sebagai sebuah konsep E-Government memiliki prinsip prinsip dasar yang universal, namun karena setiap negara memiliki skenario implementasi atau penerapannya yang berbeda, maka definisi dari ruang lingkup $E$ Government pun menjadi beraneka ragam;

b. Spektrum implementasi aplikasi $E$ Government sangatlah lebar mengingatsedemikian banyaknya tugas dan tanggung jawab pemerintah sebuah negara yang berfungsi untuk mengatur masyarakatnya melalui berbagai jenis interaksi dan transaksi;

c. Pengertian dan penerapan EGovernment di sebuah negara tidak dapat dipisahkan dengan kondisi internal baik secara makro maupun mikro dari negara yang bersangkutan, sehingga pemahamannya teramat sangat ditentukan oleh sejarah, budaya, 
pendidikan, pandangan politik, kondisi ekonomi, dari negara yang bersangkutan; dan

d. Visi, misi, strategi pembangunan sebuah negara yang sangat unik mengakibatkan terjadinya beragam pendekatan dan skenario dalam proses pengembangan bangsa sehingga berpengaruh terhadap penyusunan prioritas pengembangan bangsa.

Budi Rianto dkk (2012:39) mengatakan sedikitnya ada empat indikator keberhasilan E-Government, yaitu :

a. Ketersediaan data dan informasi pada pusat data.

b. Ketersediaan data dan informasi bagi kebutuhan promosi daerah.

c. Ketersediaan aplikasi EGovernment pendukung pekerjaan kantor dan pelayanan publik. Ketersediaan aplikasi dialog publik dalam rangka meningkatkan

d. komunikasi antar pemerintah, antara pemerintah dengan sektor swasta dan

masyarakat melalui aplikasi e-mail, SMS ataupun teleconference.

Selain itu, untuk melaksanakan maksud tersebut pengembangan Egovernment diarahkan untuk mencapai empat tujuan menurut Inpres RI No.3 Tahun 2003 tentang Kebijakan dan Strategi Nasional Pengembangan eGovernment, yaitu :

1. Pembentukan jaringan informasi dan transaksi pelayanan publik yang memiliki kualitas dan lingkup yang dapat memuaskan masyarakat luas serta dapat terjangkau di seluruh wilayah Indonesia pada setiap saat tidak dibatasi oleh sekat waktu dan dengan biaya yang terjangkau oleh masyarakat.

2. Pembentukan hubungan interaktif dengan dunia usaha untuk meningkatkan perkembangan perekonomian nasional dan memperkuat kemampuan menghadapi perubahan dan persaingan perdagangan internasional.

3. Pembentukan mekanisme dan saluran komunikasi dengan lembagalembaga negara serta penyediaan fasilitas dialog publik bagi masyarakat agar dapat berpartisipasi dalam perumusan kebijakan negara.

4. Pembentukan sistem manajemen dan proses kerja yang transparan dan efisien serta memperlancar transaksi dan layanan antar lembaga pemerintah dan pemerintah daerah otonom.

Dalam Jurnal Administrasi Negara (2006) [6] dijelaskan bahwa E-government merupakan pemanfaatan dan pendayagunaan teknologi komunikasi dan informasi dalam rangka mencapai beberapa tujuan dan kebutuhan akan :

1. Meningkatkan efisiensi dan cost efectiveness dari pemerintah;

2. Memberikan jasa pelayanan kepada masyarakat secara lebih baik;

3. Menyediakan akses informasi kepada publik secara lebih luas;

4. Menjadikan penyelenggaraan pemerintah lebih bertanggung jawab dan transparan kepada masyarakat.

Menurut Indrajit Loc.cit hlm 5 manfaat yang diperoleh dengan diterapkannya konsep e-Government bagi suatu negara, antara lain: 
1. Memperbaiki kualitas pelayanan pemerintah kepada para stakeholder-nya (masyarakat, kalangan bisnis, dan industri) terutama dalam hal kinerja efektivitas dan efisiensi di berbagai bidang kehidupan bernegara.

2. Meningkatkan trasnparansi, kontrol, dan akuntabilitas penyelenggaraan pemerintah dalam rangka penerapan konsep Good Governance.

3. Mengurangi secara signifikan total biaya administrasi,relasi, dan interaksi yang dikeluarkan pemerintah maupun stakeholdernya untuk keperluan aktivitas sehari-hari. Memberikan peluang bagi pemerintah untuk mendapatkan sumber-sumber

4. pendapatan baru melalui interaksinya dengan pihak-pihak berkepentingan.

5. Menciptakan suatu lingkungan masyarakat baru yang dapat secara tepat menjawab berbagai permasalahan yang dihadapi sejalan dengan berbagai perubahan global dan trend yang ada.

6. Memberdayakan masyarakat dan pihak-pihak lain sebagai mitra pemerintah dalam proses pengambilan berbagai kebijakan publik secara merata dan demokratis.

Sedangkan menurut Tjahjanto dalam Salam (2004:254) , manfaat terpenting dari implementasi eGovernment adalah terwujudnya pemerintahan yang lebih bertanggung jawab (accountable) bagi warganya. Selain itu, akan lebih banyak masyarakat yang bisa mengakses informasi, pemerintahan juga lebih efisien dan efektif, serta akan tercipta layanan pemerintahan yang lebih sesuai dengan kebutuhan masyarakat. Diharapkan dengan pemanfaatan yang lebih baik atas sumber daya, proses dan teknologi informasi bisa terjadi pula pemerintahan yang lebih baik.

\section{METODE PENELITIAN}

Penelitian ini menggunakan pendekatan kualitatif dengan alasan bahwa temuan-temuan dalam penelitian kualitatif tidak diperoleh melalui prosedur statistik atau bentuk hitungan lainnya serta tipe penelitian deskriptif digunakan untuk mengambarkan secara terperinci mengenai keadaan atau peristiwa yang dideskripsikan secara nyata terkait obyek yang diteliti yaitu Strategi Pemerintah Daerah Dalam Pengembangan Pelayanan Berbasis E- Government Di Kabupaten Muna.

Penelitian ini berlokasi pada Kantor Dinas Komunikasi Informatika, Statistik dan Persandian Kabupaten Muna, dengan alasan dan pertimbangan untuk mengetahui Strategi Pemerintah Daerah Dalam Pengembangan Pelayanan Berbasis E- Government Di Kabupaten Muna dan Faktor pendukung dan Faktor penghambat Pemerintah Daerah Dalam Pengembangan Pelayanan Berbasis E- Government Di Kabupaten Muna.

\section{HASIL DAN PEMBAHASAN}

Secara empiris dan Fakta setelah dilakukan observasi di lapangan maka Strategi pemerintah kabupaten Muna dalam pemgembangan pelayan berbasis EGovernment di kabupaten Muna meliputi Persiapan, Pematangan, Pemantapan dan Pemanfaatan. 


\section{Persiapan}

Persiapan berasal dari kata siap yang, mendapat awalan per dan akhiran an. Persiapan adalah perlengkapan atau persediaan untuk sesuatu agar mampu melaksanakan kegiatan dengan baik. Para ahli persipan juga bisa dimaknai dengan kesiapan. Kesiapan adalah suatu keadaan bersiap-siap untuk mempersiapkan sesuatu (kamus Besar Bahasa Indonesia, 2003). Kesiapan adalah tingkat perkembangan dari pematangan atau kedewasaan yang menguntungkan untuk mempraktekan sesuatu.(Chaplin, 2003) . Menurut Hamalik, 2008, kesiapan adalah Tingkatan atau keadaan yang harus dicapai dalam proses perkembangan perorangan pada tingkatan pertrumbuhan mental, fisik, sosial dan emosional.

Dalam perkembangannya persiapan Pemerintah daerah Kabupaten Muna dalam mengembangakan pelayanan berbasis, $E$ Government yaitu menpersiapkan seluruh perangkat-perangkat yang berhubungan dengan pelayanan berbasis E-Government. Persiapan dipersipkan secara tersktuktur karena di peruntukan untuk skala jangka panjang. Hal ini dimaksudkan agar kabupaten betul-betul di persiapkan secara matang agar pelayanan berbasi $E$ Government dapat terwujud dengan baik di kabupaten muna. Ada beberapa bentukbntuk persiapan pengembangan pelayanan berbasi E-Government di Kabupaten Muna yaitu :

a. Pembuatan Dokumen Perencanaan. Dokumen perencanaan adalah dokumen yang dibuat dengan maksud sebagai arah atau acuan dalam melakukan pengembangan pembangun untuk mewujudkan cita-cita yang di inginkan. Dokumen perencanaan dibuat dan disesuaikan dengan visi, misi dan arah pembangunan dearah yang lebih efektif, efisien,terpadu berkesinambungan dan saling melengkapi dalam pola sikap dan tindakan pelaku pembangunan. Untuk mengembangkan pelayan berbasi EGovernment di kabupaten Muna tentuntanya diperlukan dokumen perencanan agar arah adan tujuan bisa tercapai dengan baik. Berikut hasil wawancara penulis dengan kepala dinas kominfo kabupaten Muna La ode Ardian T, S.STP, terkait dokumen perencenaan pengembangan pelayanan berbasi EGovernment di Kabupaten Muna sebagai berikut :

"Kami sadari pengembangan pelayanan berbasis E-government saat ini merupakan trend dan 'bisa dianggap paling efisien untuk mempermudah masyarakat dalam hal mendapatkan pelayanan, kabupaten Muna tentunya akan melakukan hal yang sama, tetapi kita perlu ketahui bahwa untuk mewujudkan itu tentunnya harus dipersipkan dengan matang, terkait dokumen perencanaan kami sudah buat sebagai penguat untuk pengembangannya kedepan. Terkait dokumen perencaan ini menjadi factor utama dan yang terpenting karena dari dokumen perencanaan sebagai bahan acuan kami dan arah dalam mengembangkan Pelayanan barbasis E-government di Kabupaten Muna ini”.

Dari hasil wawancara dengan kepala dianas Kominfo Kabupaten Muna terkait dokumen perencenaan pengembangan pelayanan berbasis E- 
Government di Kabupaten Muna dapat menunjukan bahwa untuk perencaan dokumen telah dibuat sebagai bagian dari acuan utama dalam pengembangan pelayanan berbasis E-government di Kabupaten Muna. Tanpa ada dokumen perencanaan arah dan tujuan dalam mengembangkan pelayanan berbasis Egovernment di Kabupaten Muna tidak akan berjalan dengan baik.

\section{b. Blue print Smarcity}

Blue print adalah suatu rancangan yang dirumuskan untuk meberikan arah dengan tujuan untuk memberikan arah terhadap kegiatan komunitas atau organisasi secara berkesinambungan sehingga setiap kegiatan memiliki kebersesuaian dengan tuntutan dan tantangan dan kebutuhan lingkungan sekitar, merupakan bentuk kerangka kerja yang terperinci sebagai landasan dam pembuatan kebijakan. Untuk mewujudkan pengembangan layanan berbasis $E$ Government di Kabupaten Muna diperlukan Blue print. Berikut wawancara penulis dengan kadis kominfo Kabupaten Muna La ode Ardian T, S.STP, terkait kegunaan Blue print sebagai arah acuan dalam mengembangkan pelayanan berbasis E-government di Kabupaten Muna sebagai berikut :

"Mengenai kegunaan blue print dalam mengembangkan pelayanan berbasis E-government di Kabupaten Muna, sangat diperlukan sekali.langkah awal yang menjadi prioritas untuk di buat sebagai bagian dari persiapan karena dalam blue print itu akan digambarkan dan menetapkan tujuan serta sasaransasaran yang akan dihasilkan, bukan saja itu diblue print juga kita akan menyusun strategi dalam mengembangkan pelayanan berbasis E-government di Kabupaten Muna, bahkan diblue print juga akan digambarkan bagaimana peleksanaan program dan fokus kegiatan".

Dari hasil wawancara dengan kepala dianas kominfo Kabupaten Muna terkait terkait kegunaan Blue print sebagai arah acuan dalam mengembangkan pelayanan berbasis E-government di Kabupaten Muna dapat dimpulkan dan menunjukan blue print sangat diperlikan sebagai acuan dalam proses pelaksanaan pengembangan pelayanan berbasis E-government di Kabupaten Muna karena dengan adanya blue print akam memudahkan apa yang akan dilakukan, didalam blue print telah ada juga penetapan tujuan dan sasaran, penyusunan strategi serta pelekasanaan program dan fokus kegiatan.

\section{c. Pembuatan Website}

Website adalah suatu dokumen atau berupa kumpulan halaman web yang saling berhubungan dan isinya terdiri dari berbagai informasi berbentuk teks, suara gambar, video dan lainnya dimana semua data tersebut disimpan pada server hoting. Menurut sibero Website adalah suatu system yang berkaitan dengan dokumen yang digunakan media, untuk menampilkan teks, gambar, multimedia dan lainnya pada jaringan internet, sedangkan menurut hidayat pengertian website adalah keseluruhan halamanhalaman web yang terdapat dalam sebuah domain, yang mengandung informasi, sebuah website dibangun atas banyak halaman web yang saling berhubungan.dalam mengembangkan pelayanan berbasis E-government di kabupaten Muna salah satu pendukung dan 
masuk persiapan awal adalah dengan pembutan website. Berikut wawancara dengan kepala dinas kominfo Kabupaten Muna La ode Ardian T, S.STP, terkait pembuatan website dikabuten Muna sebagai berikut :

"Terkait pembuataan website secara khusus di dinas kominfo ini sudah ada.tetatpi yang kami inginkan adalah semua instansi yang ada dilingkup di kabupaten Muna harus semua ada agar ketika nanti pelayanan berbasi online di terpakan maka persiapan website ini yang paling utama.ini tugas kami untuk intes berkomunikasi dengan instansiinstansi yang ada di kabupaten Muna yang kita cintai ini."

Dari hasil wawancara dengan kepala dianas kominfo Kabupaten Muna terkait kominfo Kabupaten Muna terkait pembuatan website di Kabupaten Muna dapat disimpulkan dan menunjukan keberadaan website adalah hal yang paling utama. Secara khusus di dinas Kominfo Kanupaten Muna terkait Websaite itu sudah ada. Tetapi tanggung jawab mereka agar instansi-instansi yang ada di Kabupaten Muna harus memiliki website masing. Mengingat tanpa adanya website proses pelayanan berbasis E-government di kabupaten Muna tidak akan berjalan lancer karena persiapan utamanya tidak disediakn. Olehnya itu keberaadan Website sangat dibutuhkan.

d. Pengembangan jaringan infrastruktur telekomunikasi dasar Sejarah

telekomunikasi terus mengalami perkembangan dari zaman kezaman. Perkembangan telekomunikasi dari masa kenasa ini yang telah diciptakan dengan tujuan mempermudah manusia dalam mendaptkan informasi yang lebih mudah. secara defenisi Telekomunikasi berasal dari dua kata tele artinya jauh dan komunikasi artinya suatu penyampaian informasi pesan,ide, gagasan, dari satu pihak-kepihak lain. Jadi telekomunikasi adalah suatu proses penyampaian informasi, dalam bentuk pesan ide maupun gagasan-gagasan dari satu pihak kepihak lain yang dilakukan dalam jarak jauh. Dalam pengembangan pelayanan berbasis E-government di kabupaten Muna persiapan yang dilakukan adalah dengan pengembnangan jaringan infrastruktur telekominikasi dasar. Berikut wawancara penulis dengan kepala dinas kominfo kabupaten Muna La ode Ardian T, S.STP, terkait Pengembangan jaringan infrastruktur telekomunikasi dasar adalah sebagai berikut :

"Terkait pengembangan
infrastruktur
jaringan telekomunikasi dasar kami saat ini
telerlah memetahkan dulu atau
zonasi daerah-daerah mana saja
saat ini yang ada di kabupaten
muna yang belum tersentuh
jaringan kebanyakan ada didaerah
sebrang dan bagian muna daratan.
Salh satu contoh misalnya
kecamatan batukara dan
kecamatan marobo
disanaberbicara telekomunikasi
informasi dan tidak ada begitu pula yang
sangat tidak
ada dikecamatan matrobo dan
kecamaataan pasikolaga".
Hal senada juga disampaikan oleh
batukara Laode Hayari afu, S.Sos,
Pengembangan jaringan


infrastruktur telekomunikasi dasar adalah sebagai berikut :

"Kami dikematan batukara ini bicara telekomunilkasi sebagian besar belum ada jaringan telekomunikasi. Untuk saling berkomunikasi sangat susah. Apalagi kalau kita butuh informasi dari kabupaten itu sangat susah mendapat informasi up date biasa sudah lewat kegiatan-kegiatan pemerintahan baru kami dapat informasi. Itu salah salah satu contoh saja.masih banyak lagi contoh-contoh lain.olehnya itu kami perlu sekali jaringan telekomunikasi terpasang didaerah kami atau perangkat-peranhgkat yang menunjang lainnya. Tapi saat ini pemerintah kabupaten Muna melaui kadis kominfo sudah mewacanakan pemasangan jarinagan telekomunikasi tersebut".

Dari hasil dua wawancara diatas dengan kepala dianas kominfo Kabupaten Muna dan camat batukara terkait Pengembangan jaringan infrastruktur telekomunikasi dasar dapat disimpulkan dan menunjukan bahwa kebutuhan infrastruktur jaringan telekomunikasi dasar sangat diperlukan.masih ada beberapa daerah yang ada di kabupaten Muna yang tidak tersentuh sama sekali jaringan telekomunikasi dasar yaitu kecamatan batukara, kecamatan marobo ,dan kecamaatan pasikolaga. Dengan kata lain kominfo Kabupaten Muna telah berupaya memasang perangkat-perangkat jaringan telekomunikasi didaerah-daerah yang belum ada jaringan telekomunikasi teresebut. e. Pendekatan dengan Pihak Swasta Dalam upaya pengembangan pelayanan berbasis E-government keterlibatan pihak swasta sangat diharapkan. Dukungan pihak swasta sangat mendorong upaya percepatan pembangunan. Pemerintah daerah bisa bekerja dengan swasta bukan soal dalam hal pendanaaan tetapi bentuk-bentuk kerja sama lainnya sangat dioerlukan misalnya peningkatan skill SDMnya untuk membangun dan memelihara infrastruktur yang belum dan sudah tersedia dalam rangka meningkatkan kualitas layanan. Kabupaten Muna atau pemerintah daerah dalam mengembangkan pelayanan berbasis berbasis E-government di Kabupaten Muna bekerja sama dengan pihk swasta. Berikut wawancara dengan kepala dinas kominfo kabupaten Muna La ode Ardian T, S.STP ,terkait Pendekatan dengan Pihak Swasta adalah sebagai berikut:

$$
\text { "Terkait pendekatan }
$$

dengan pihak swasta kami telah mengupayakan salah satunya pendekatan dengan PT.telkom. alhmdulilah pikah dari Telkom bersedia bekerja sama dengan pemerintah Kabupaten Muna untuk megembangkan pelayanan berbasis E-Government di Kabapaten Muna langkah awal atau sebagai permulaan awal yaitu mensurvei semau daerah-daerah yang ada Di Kabupaten Muna yang belum tersentuh dengan jarinngan telekomunikasi."

Dari hasil wawancara dengan kepala dianas kominfo Kabupaten Muna terkait terkait Pendekatan dengan Pihak Swasta dalam mengembangkan pelayanan 
berbasis E-government di Kabupaten Muna dapat dimpulkan dan menunjukan bahwa keterlibatan pihak swasta dalam mengembangkan pelayanan berbasis Egovernment di Kabupaten Muna sangat diharapkan. Kehadiran pihjak swsasta dapat mempercpat proses pengembangannya terutama mnegenai teknis lapangan. Pihak swasta yang menjadi mitra kerja sama adalah PT.Telkom.

\section{Pematangan}

Pematangan adalah suatu proses atau suatu keadaaan dalam pencapaian proses dengan kata lain telah mencapai perkembangan dalam melakukan suatu kegiatan. Dalam hal pematangan dalam pelayanan berbasis E-government di Kabupaten Muna yaitu pematangan terkait ketersediaan seluruh perangkat persiapan. Langkah-langkah pemerintah kabupaten muna dalam proses pematangan pelayanan berbasis E-government di Kabupaten Muna yaitu sosialisasi dan singkronisasi kejibakan 1 data keleseluruh OPD.

a. Sosialisasi

Menurut kamus besar bsar bahasa Indonesia sosialisasi berarti memasyarakatkan sesuatu sehingga menjadi dikenal, dipahami, dihayati oleh masyarakat atau pemasyarakatan. Sosialisasi sangat penting adanya karena bila tidak ada sosialisasi maka bisa dipastikan apapun tujuan yang kita maksudkan untuk diri kita sendiri maupun orang lain tidak akan tercapai. Sosialisasi dapat diartikan juga interaksi antar manusia sebagai anggota kelompok. Sosialisasi merupakan baimana memperkenalkan sebuah sistem pada seseorang atau individu dimana bagaimana orang tersebut menentukan tanggapan dan reaksinya.

Kegiatan sosialisasi tidak hanya menyampaikan informasi tentang yang akan disampaikan, tetapi juga mencari juga sebuah dukungan dari berbagai dukungan masyarakat. Dalam pengembangan pelayanan berbasis E-government di Kabupaten Muna hal yang paling utama juga adalah sosialisasi tentang program agar semua masyarakat dapat mengetahuinya. Sosialisasi dapat memberikan dua kontribusi secara fundamental terhdap kehidupan kita. Pertama, memberikan dasar atau fondasi kepada individu bagi terciptanya partisipasi yang efektif dalam masyarakat, dan kedua memungkinkan lestarinya suatu masyarakat, karena tanpa sosialisasi akan hanya ada satu generasi saja sehingga kelestarian masyarakat akan sangat terganggu. Berikut wawancara dengan kepala dinas kominfo kabupaten Muna La ode Ardian T, S.STP, terkait sosialisasi pengembangan pelayanan berbasis $E$ government di Kabupaten Muna adalah sebagai berikut:

"Terkait sosialisasi mengenai
pelayanan berbasis E-government di
Kabupaten Muna saat ini yang kami
lakukan adalah mensosialisasikan
kepada seluruh masyarakat, OPD
agar semua stakeholder dapat
mengetahui tentang keunggulan
program ini,persiapan-persiapan
yang kami lakukan perlu juga
disosialisasikan. Untuk lebih
suksesnya program ini sosialisasi
sangat diharapkan. Kami bahkan
turun sampai kekecamatan-kecamatan
sosialisasikan terutama pada
kecamatan-kecamatan yang tidak


pernah sama sekali tidak ada jaringan internet, dan sekaligus memetakan zona-zona mana yang menjadi titik prioritas."

Hal senada juga diungkapkan oleh Rismadin salah masyarakat yang ada didesa moolo kecamatan batukara terkait sosialisasi pengembangan pelayanan berbasis E-government di Kabupaten Muna adalah sebagai berikut:

"Untuk sosialisai terkait sosialisasi pengembangan pelayanan berbasis E-government di Kabupaten Muna memang pemetrintah Kabupaten Muna sudah pernah melakukan sosialisasi dikecamatan kami ini, bahkan kami dijanjikan akan segera diadakan didesa kami ini, jujur kalau kami di moolo ini kalau dibilang terlambat informasi kami harus akui karena tidak ada jaringan internet,jangankan menghubungi pemerintah mau hubungi keluarga yang berbeda daerah saja susah terkeculi pergi ditempat-tempat yang dekat dan dapat menerima jaringan internet".

Camat pasikolaga Halim, S.Pd, pun saat wawancara mengungkapkan bahwa terkait sosialisasi pengembangan pelayanan berbasis E-government di Kabupaten Muna adalah sebagai berikut:

"Sosialisasi pengembangan pelayanan berbasis E-government di Kabupaten Muna sangat perlu sekali kerena saya yakin bahwa tidak semua masyrakat paham tentang program ini, program ini sangat bagus tingggal diperkut lagi sosialisasinya.kami dipasikolaga ini memang masih ada satu desa yang belum ada jaringan yaitu di desa kolese bagian atas itu tidak ada jaringan internet sedangkan didesa-desa lain sudah ada seperti jaringa 4G. cuman masih dominan loadingnya tetapi sudah ada jaringannya.jadi dengan adanya program ini tinggal ditingkatkan lagi'.

Dari hasil wawancara dengan ketikga informan diatas terkait sosialisasi pengembangan pelayanan berbasis Egovernment di Kabupaten Muna menunjukan bahwa sosialisasi sangat dibutuhkah dan dinggap perlu oleh masyararat agar program ini berjalan dengan baik dan kita dapat menikmati perkembangan pelayanan berbasis Egovernment di Kabupaten Muna secara cepat. konsep Smarcity harus diwujudkan terkhusus di kabupaten Muna. Sosialisasi pun membuka/ mendorongpeluang percepatan pembagunan program ini.

b. Singkronisasi Kebijakan 1 data Keleseluruh Organisasi Pemerintah Daerah (OPD).

Menurut kamus Besar Bahasa Indonesia (Departemen Pendidikan Nasional, 2012) kata Singkron berarti terjadi atau berlaku pada waktu yang sama, serentak, sejalan, sejajar, sesuai dan selaras. Menurut Endang Sumiarni (2013), sinkronisasi adalah melihat kesesuaian atau keselarasan peraturan perundangundangan secara vertikal berdasarkan sistematisasi hukum positif yaitu antara peraturan perundangundangan yang lebih tinggi dengan peraturan perundangundangan yang lebih rendah.

Di pengertian yang lain Sinkronisasi adalah suatu penyelarasan dan penyelerasian berbagai peraturan perundang-undangan yang terkait dengan 
peraturan perundang-undangan yang telah ada dan yang sedang disusun yang mengatur suatu bidang tertentu. Proses sinkronisasi peraturan bertujuan untuk melihat adanya keselarasan antara peraturan yang satu dengan peraturan lainnya. Sinkronisasi dilakukan baik secara vertikal dengan peraturan di atasnya maupun secara horizontal dengan peraturan yang setara. Dalam pengembangan pelayanan berbasis $E$ government di Kabupaten Muna, langkah yang perlu dilakukan adalah sikronisasi Kebjakan 1 data Keleseluruh Organisasi Pemerintah Daerah (OPD). Berikut wawancara penulis dengan kepala dinas kominfo kabupaten Muna La ode Ardian T, S.STP , terkait Singkronisasi Kebjakan 1 data Keleseluruh Organisasi Pemerintah Daerah (OPD) dalam pengembangan pelayanan berbasis E-government di Kabupaten Muna adalah sebagai berikut :

"Terkait singkronisasi Kebjakan 1 data Keleseluruh Organisasi Pemerintah Daerah (OPD) saat ini yang kami lakukan adalah melakukan pendekatan-pendekatan dengan Organisasi Pemerintah Daerah (OPD) sebagai penguatan untuk mengembangkan pelayanan berbasis E-government di Kabupaten Muna. Saya lira Perlu dipahami bahwa tanpa adanya singkronisasi maka program sebaik apapun tidak berjalan maksimal atau tidak berjalan baik, minimal masing-masing $O P D$ sebagai standar mempunyai website yang bisa diakses oleh masyarakat. kami juga akan membentuk tim atau teknisi dimana anggotanya kami memimta masing-masing 1 orang per $O P D$ dan orang-orang inilah yang akan mengintegrasikan data Website, serta aplikasi se Kabupaten Muna".

Dari hasil wawancara dengan Kadis kominfo terkait Singkronisasi Kebjakan 1 data Keleseluruh Organisasi Pemerintah Daerah (OPD) dalam pengembangan pelayanan berbasis Egovernment di Kabupaten Muna menunjukan bahwa kominfo kabupaten muna telah menjajaki kerja sama dengan seluruh Organisasi Pemerintah Daerah (OPD) dengan tujuan agar program pengembangan pelayanan berbasis Egovernment di Kabupaten Muna berjalan dengan baik. Sebagai standar awal seluruh Organisasi Pemerintah Daerah (OPD) memiliki Website agar masyarakat mudah mengakses informasi-informasi di masingMasing Organisasi Pemerintah Daerah (OPD). Selain itu kominfo Kabupaten Muna akan membentuk Tim dimana angota-anggotanya dari OPD yang ada di kabupaten Muna masing-masing satu orang dan tim inilah yang akan ditugaskan mengintegrasikan data Website, serta aplikasi se Kabupaten Muna.

\section{Pemantapan}

Menurut kamus besar bahasa Indonesia Pemantapan adalah proses atau cara perbuatan memantapkan (Meneguhkan, Menjadikan dan stabil). Pemantapan yaitu kegiatan untuk mengetahui segala bentuk perkembangan suatu program atau pekerjaan. Pemantapan pengembangan pelayanan berbasis $E$ government di Kabupaten Muna adalah semua kegiatan yang bertujuan untuk menjamin ketelitian dalam pelaksanaan program pelaksanaan pengembangan pelayanan berbasis E-government di Kabupaten Muna. Berikut wawancara penulis dengan kepala dinas kominfo 
kabupaten Muna La ode Ardian T, S.STP, terkait Pemantapan dalam pengembangan pelayanan berbasis E-government di Kabupaten Muna adalah sebagai berikut :

"Terkait pemantapan dalam pengembangan pelayanan berbasis Egovernment di Kabupaten Muna, saat ini yang kami lakukan selain memantapkan persiapan teknis-teknis ataupun perangkat-perangkat keperluan pengembangan pelayanan berbasis E-government di Kabupaten Muna, kami juga mengembangkan dan menyiapkan sumberdaya manusia terkait dengan kemapuan ASN di kabupaten Muna untuk memahami dan fungsi serta peningkatan kemampuan teknis dalam megelola dan melayami dengan menggunakan E-government di Kabupaten Muna”.

Dari hasil wawancara dengan Kadis kominfo terkait Pemantapan dalam pengembangan pelayanan berbasis $E$ government di Kabupaten Muna menunjukan bahwa Pemerintah kabupaten Muna melaui Dinas kominfo kabupaten Muna menyiapkan Apratur sipil Negara khusus di kabupaten Muna untuk memahami, mengetahui serta menyiapkan diri untuk melayani masyarakat kabupaten Muna dengan menggunakan pelayanan berbasis E-government.cara pemantapan yang dilakukan adalah dengan mengikut diklat-diklat teknis sebagai pendukung kemampual skill para ASN yang ada di Kabupaten Muna.

\section{Pemanfaatan}

Secara harfiah Pemanfaatan berasal dari kata dasar manfaat yang berarti guna atau bisa di diartikan berfaedah. Menurut kamus besar bahasa Indonesia (2002) Pemanfaatan memiliki makna proses, cara atau perbuatan memanfaatkan. Pemanfaatan adalah suatu kegiatan, proses, cara atau perbuatan menjadikan suatu yang ada menjadi bermanfaat. Sedangkan ,menurut Poerwadarminto (2002) Istilah pemanfaatan berasal dari kata dasar manfaat yang berarti faedah, yang mendapat imbuhan pe-an yang berarti proses atau perbuatan memanfaatkan .

Pemanfaatan juga diartikan sebagai turunan dari kata manfaat yakni suatu penghadapan yang semata-mata menunjukan kegiatan menerima. Dengan maksud pengahapan pada umumnya mengarah pada perolehan atau pemakaian hal-hal yang berguna baik dipergunakan secara langsung maupun tidak langsung agar dapat bermanfaat. Dalam pemgembangan pelayanan berbasis $E$ government di Kabupaten Muna pemanfaatan dimaksudkan agar masyarakat dapat mudah mendapat akses pelayanan. Berikut wawancara penulis dengan kepala dinas kominfo kabupaten Muna La ode Ardian T, S.STP, terkait Pemanfaatan dalam pengembangan pelayanan berbasis E-government di Kabupaten Muna sebagai berikut :

"Terkait pemanfaatan Pelayaanan berbasis E-government di Kabupaten Muna.ini boleh dikatan tahapan paling akhir dalam artian tahapan ini sudah bisa diaplikasikan dan bisa dimanfaatkan oleh seluruh masyarakat kabupaten Muna dan tentunya seluruh OPD harus siap melaksanakan pelayanan berbasis Egovernment di Kabupaten Muna”.

Dari hasil wawancara dengan Kadis kominfo terkait Pemanfaatan pengembangan pelayanan berbasis $E$ government di Kabupaten Muna menunjukan bahwa pada tahapan 
pemafaatan merupakan rangkain akhir tahapan pengembangan,pada tahapan ini maksudkan agar masyarakat memanfaatkan kemudahan akses pelayanan diseluruh organisasi pemerintahan Daerah (OPD).

\section{KESIMPULAN}

Adapun yang menjadi kesimpulan terkait stratergi pemerintah Pemerintah Daerah Dalam Pengembangan Pelayanan Berbasis E- Government Di Kabupaten Muna adalah strategi pemerintah kabupaten Muna dalam pemgembangan pelayan berbasis E- Government di kabupaten Muna meliputi Persiapan, Pematangan, Pemantapan dan Pemanfaatan. Persiapan yaitu Pembuatan Dokumen Perencanaan, Blue print Smarcity, Pembuatan Website, Pengembangan jaringan infrastruktur telekomunikasi dasar dan Pendekatan dengan Pihak Swasta. Pematangan: Melakukan sosialisasi, Singkronisasi Kebjakan 1 data Keleseluruh Organisasi Pemerintah Daerah (OPD). Pemantapan: Pemerintah kabupaten Muna melaui Dinas kominfo kabupaten Muna menyiapkan Apratur sipil Negara khusus di kabupaten Muna untuk memahami, mengetahui serta menyiapkan diri untuk melayani masyarakat kabupaten Muna dengan menggunakan pelayanan berbasis Egovernment dan pemanfaatan : pada tahapan pemafaatan merupakan rangkain akhir tahapan pengembangan,pada tahapan ini maksudkan agar masyarakat memanfaatkan kemudahan akses pelayanan diseluruh organisasi pemerintahan Daerah (OPD).

\section{DAFTAR PUSTAKA}

I. Ang, "Globalisation and culture," Continuum. 1994, doi: 10.1080/10304319409365684.

R. E. . Indrajit, Electronic Government Strategi Pembangunan dan Pengembangan Sistem Pelayanan Publik Berbasis Teknologi Digital. Yogyakarta, 2006.

Rivai dan Darsono, Manajemen Strategis. Jakarta, 2015.

S. H. Winarno, "Penilaian Kinerja

Keuangan Perusahaan Melalui

Analisis Rasio Profitabilitas," $J$.

Ilm. Akunt. dan Bisnis, 2017.

\section{Jurnal}

E. M. Ramdani, “Analisis Efektivitas Pelaksanaan E Government di Tingkat Kelurahan," Sawala J. Adm. Negara, 2018, doi: 10.30656/sawala.v6i1.520.

\section{Peraturan Perundang - Undangan Intruksi Presiden No 3 Tahun 2003 tentang Kebijakan dan Startegi Nasional Pengembangan E.Government .}

